\title{
CONTEMPORARY JAPANESE CINEMA SINCE HANA-BI
}




\section{Traditions in World Cinema}

General Editors

Linda Badley (Middle Tennessee State

University)

R. Barton Palmer (Clemson University)

Founding Editor

Steven Jay Schneider (New York University)

Titles in the series include:

Traditions in World Cinema

by Linda Badley, R. Barton Palmer and Steven Jay Schneider (eds)

Japanese Horror Cinema

by Jay McRoy (ed.)

New Punk Cinema

by Nicholas Rombes (ed.)

African Filmmaking

by Roy Armes

Palestinian Cinema

by Nurith Gertz and George Khleifi

Chinese Martial Arts Cinema

by Stephen Teo

Czech and Slovak Cinema

by Peter Hames

The New Neapolitan Cinema

by Alex Marlow-Mann

American Smart Cinema

by Claire Perkins

The International Film Musical

by Corey Creekmur and Linda Mokdad (eds)
Italian Neorealist Cinema

by Torunn Haaland

Magic Realist Cinema in East Central

Europe

by Aga Skrodzka

Italian Post-Neorealist Cinema

by Luca Barattoni

Spanish Horror Film

by Antonio Lázaro-Reboll

Post-beur Cinema

by Will Higbee

New Taiwanese Cinema in Focus

by Flannery Wilson

International Noir

by Homer B. Pettey and R. Barton Palmer (eds)

Films on Ice

by Scott MacKenzie and Anna Westerståhl Stenport (eds)

Nordic Genre Film

by Tommy Gustafsson and Pietari Kääpä (eds)

Contemporary Japanese Cinema Since

Hana-Bi

by Adam Bingham

Chinese Martial Arts Cinema

by Stephen Teo

www.euppublishing.com/series/tiwc 


\section{CONTEMPORARY JAPANESE CINEMA SINCE HANA-BI}

Adam Bingham 
(C) Adam Bingham, 2015

Edinburgh University Press Ltd The Tun - Holyrood Road 12 (2f) Jackson's Entry

Edinburgh EH8 8PJ

www.euppublishing.com

Typeset in 10/12.5 pt Sabon by

Servis Filmsetting Ltd, Stockport, Cheshire and printed and bound in Great Britain by

CPI Group (UK) Ltd, Croydon CR0 4YY

A CIP record for this book is available from the British Library

ISBN 9780748683734 (hardback)

ISBN 9780748683741 (webready PDF)

ISBN 9780748683765 (epub)

The right of Adam Bingham to be identified as author of this work has been asserted in accordance with the Copyright, Designs and Patents Act 1988 and the Copyright and Related Rights Regulations 2003 (SI No. 2498). 